\title{
How do self-employed Sámi people perceive the impact of the EU and globalisation?
}

\author{
Leo Paul Dana* and Teresa E. Dana \\ University of Canterbury, \\ Private Bag 4800, Christchurch, New Zealand \\ E-mail: Leo.Dana@canterbury.ac.nz \\ E-mail: Teresa.Dana@canterbury.ac.nz \\ ${ }^{*}$ Corresponding author
}

\begin{abstract}
Free trade agreements and the decrease of barriers to trade have facilitated international business in many parts of the world. Simultaneously, globalisation has been beneficial for many. For Sámi people, there have been two sides of globalisation; while globalisation has brought an increase in technology and consumer goods, there has also been an increased need for cash, pulling people from traditional self-employment. Furthermore, the man-made boundaries, that today define nation-states, have ignored the traditional movements of Sámi people. European Union legislation is disrupting traditional trade routes while globalisation is altering traditional lifestyles. Based on in-depth interviews, our research shows that globalisation is changing the nature of Sámi self-employment. Among the external causes of change are new requirements for meat processing; these are insensitive to local traditions and reported as being less efficient. Herding activities are becoming increasingly mechanical as globalisation pushes the reindeer economy to become a meat production business. Relating to the literature, the modernisation and dependency perspectives present incompatible views of the relationship between the Sámi people and the developed world; the modernisation prescription is mismatched with Sámi objectives relating to their traditions, culture and values and the role that these are to play in development.
\end{abstract}

Keywords: globalisation; self-employment; entrepreneurship; reindeer; modernisation; change.

Reference to this paper should be made as follows: Dana, L.P. and Dana, T.E. (2007) 'How do self-employed Sámi people perceive the impact of the EU and globalisation?', Int. J. Business and Globalisation, Vol. 1, No. 1, pp.3-19.

Biographical notes: Leo Paul Dana holds degrees from McGill University and from the Ecole des Hautes Etudes Commerciales. He has been tenured at the University of Canterbury since 1999. He is also Adjunct Professor of Entrepreneurship in the Faculty of Business Administration, at the University of Regina. He formerly served as Visiting Professor of Entrepreneurship at INSEAD and Deputy Director of the International Business MBA Programme at Nanyang Business School, in Singapore.

Teresa E. Dana holds degrees from Concordia University and McGill University. She is Senior Lecturer at the University of Canterbury. Prior to that she taught at the Christchurch College of Education (New Zealand); at Nanyang Technological University (Singapore); at ICN Business School (France) and at Concordia University (Canada). 


\section{Introduction}

Before WWII, Olson wrote,

"the five countries of the North - Finland, Sweden, Denmark, Norway and Iceland - are trying to break down border and trade and customs barriers, to codify their laws, to emphasise cultural alikeness in ideals." (Olson, 1938, p.553)

Globalisation was already on its way and Sámi culture was being ignored.

Following the post-modern movement of the late 20th century (Richardson, 1997), the 3rd millennium ushered in the current seventh movement that has been calling for the social sciences to become sites for critical discussions about globalisation, community, nation-states and race (Denzin and Lincoln, 2003). This paper looks at the impact of globalisation on communities that pre-date nation-states. It reports on field research conducted in Fenno-Scandia, ${ }^{1}$ home of the Europe Union's only officially-recognised Indigenous group - the Sámi - a people who have become associated with the reindeer, Rangifer tarandus. Here, in Fenno-Scandia, reindeer pastures cover $40 \%$ of the land (Turi, 2002).

Fenno-Scandia includes the reindeer herding areas of the northernmost regions of Finland (Lapland); Norway (Finnmark, Nordland, and Troms); and Sweden (Norrbotten). Of these countries, Finland is the most integrated into the European Union; it is the only one to use the euro. Unlike Finland and Sweden, Norway is not part of the European Union.

Traditionally, Sámi reindeer herders were nomads, ${ }^{2}$ or semi-nomads, reading the signals of their reindeer and following the herds across national boundaries. For these people, self-employment revolved around reindeer and the extended family was the work unit (see Figure 1). In the absence of private ownership of land, groups of families respected traditional usage rights. This form of production involved sharing and specialising - in the absence of markets as defined by modern Western society. When people had a surplus (i.e., more food than they could consume before it lost its freshness), a common practice was to share, without accepting monetary compensation. Although there were no labour markets, there was mutual exchange within a kin group.

During the 19th and 20th centuries, the Sámi people were forced to live within unnatural borders and traditional trade patterns were interrupted by regulations legislated hundreds of kilometres away. While some aspects of Sámi life have remained constant for centuries, vast changes are taking place, as lawmakers for the European Union appear to ignore local culture, traditional relationships and proven practices. Some policy-makers have little understanding of northern Fenno-Scandia and new rules (such as trucking reindeer to distant slaughter-houses) are having a negative impact. Nevertheless,

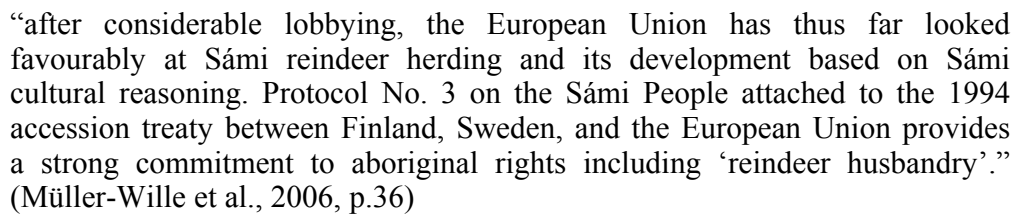

"after considerable lobbying, the European Union has thus far looked favourably at Sámi reindeer herding and its development based on Sámi cultural reasoning. Protocol No. 3 on the Sámi People attached to the 1994 accession treaty between Finland, Sweden, and the European Union provides a strong commitment to aboriginal rights including 'reindeer husbandry'." (Müller-Wille et al., 2006, p.36) 
While herding continues to be a communal activity, the individual ownership of each reindeer remains private. The question arises, however, "What is the impact of globalisation on the Sámi?" The objective of our study was to address this.

Figure 1 Extended family at spring round-up

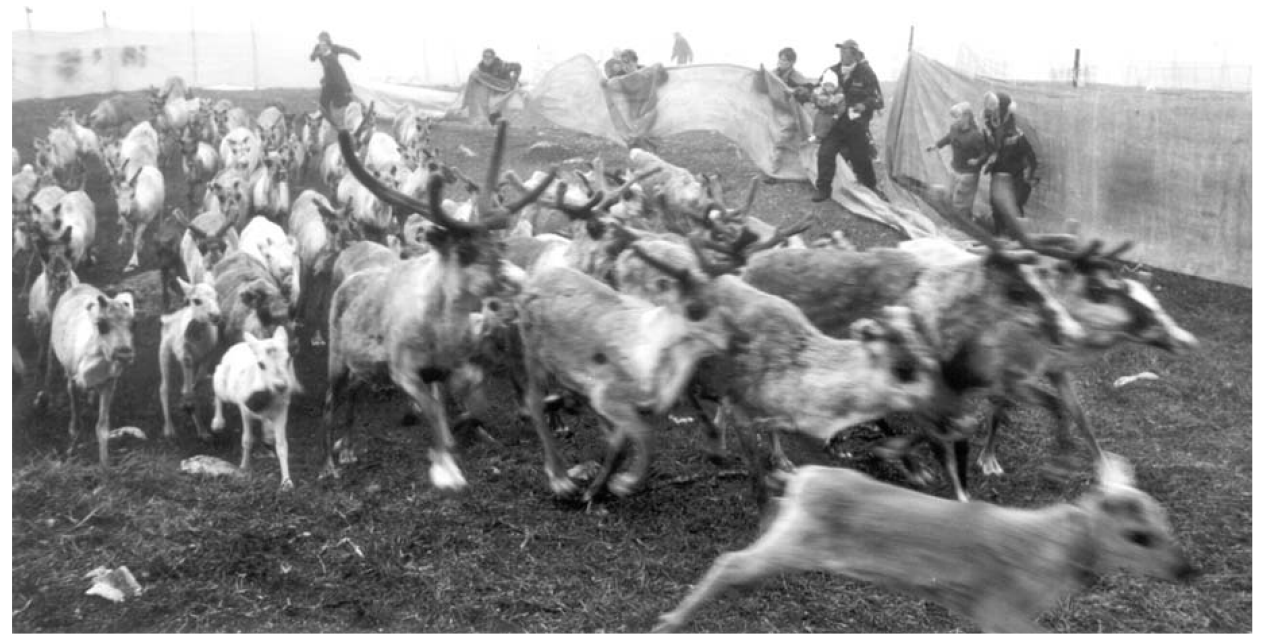

\title{
2 Theoretical framework
}

Graburn defined the Fourth World as, "those native peoples whose lands and cultures have been engulfed by the nations of the First, Second and Third Worlds" (Graburn, 1981, p.61). These peoples, including the Sámi, are commonly referred to as Indigenous. Around the world, Indigenous people are struggling to reassert their nationhood within the post-colonial states in which they find themselves (Anderson et al., 2006).

Like other Indigenous peoples, the Sámi traditionally relied mostly on local sources, for food and for their energy requirements. Beginning in the 1950s, the Sámi became increasingly dependent on imported fuel and the snowmobile increased dependency. Müller-Wille wrote,

\begin{abstract}
"one can refer to the modification of the reindeer economy in Northern Fennoscandia with the use of the snowmobile and the motorcycle between 1962 and 1968; this meant a considerable financial outlay for the Lapp reindeer herder and led to a reindeer meat industry oriented to a market economy." (Müller-Wille, 1978, p.110)
\end{abstract}

The modernisation perspective (Rostow, 1953, 1957, 1960) equates development with economic growth and industrialisation. According to Moore $(1963,1979)$, modernisation refers to a total transformation of a traditional or pre-modern society. Levy (1966) defined modernisation as the ratio of inanimate to animate sources of power. Berger et al. suggested that modernisation

"must be seen in close relation to economic growth - more specifically, to the particular growth processes released by recent technology." (Berger et al., 1973, p.8) 
As explained by So (1990), dependency theory critiques the modernisation perspective, and links lack of development to capitalism and globalisation.

The modernisation and dependency perspectives remain irreconcilable one with the other and with many of the actual outcomes in developing regions. Rejecting both, Corbridge suggested:
"The changing contours of global production are no more accessible to accounts of modernisation theory and neoclassical economics than they are to Marxist Development Studies (MDS): indeed, a metatheoretical commitment to the logic of diffusion or to freely functioning markets is even less fitted to the task than is a faith in the development of underdevelopment." (Corbridge, 1990, p.624)

He elaborated that there is a powerful trend,

"towards theories of capitalist development which emphasise contingency ... a new emphasis on human agency and the provisional and highly skilled task of reproducing social relations." (Corbridge, 1990, p.633)

Regulation theory ${ }^{3}$ approaches the global economy with a focus on regimes of accumulation (Storper and Walker, 1989) and social regulation (Peck and Tickell, 1992). The regime of accumulation determines the general possibilities for the economy where "surplus is generated, appropriated, and redeployed" (Scott, 1988, p.8).

Dicken (1992, p.307) argued that successful participation in the global economic system is a function of "economic structures, values, cultures, institutions and histories". This can occur when a group chooses to 'opt in' and actively participate in the global economy. That participation can be characterised by the degree to which the group passively accommodates itself to the requirements of the global economy (Anderson et al., 2006). Dunning suggested,
"If we can 'get it right' (and getting it 'right' includes the right way to globalise) global capitalism, as it is now emerging, can help achieve many of the economic and social goals and aspirations which most people hold dear, better than any other alternative currently on offer." (Dunning, 2003, p.11)

Norwegian politician Johan Sverdrup told the Norwegian Parliament that the only salvation for Sámi people was to be absorbed into mainstream society (Bjørklund, 1985). As globalisation accelerated during the 20th century, many believed that Indigenous peoples were destined to become assimilated in mainstream society (Aikio, 1993). Yet, Huntington $(1993,1996)$ showed that globalisation neither standardised societies, nor produced a homogeneous world culture. Daes asserted,

\footnotetext{
"In many ways, Indigenous peoples challenge the fundamental assumptions of globalisation. They do not accept the assumption that humanity will benefit from the construction of a world culture of consumerism." (Daes, 2003, p.67)
}

She argued that globalisation "is dissolving all cultures into a single supermarket with standard brands" (Daes, 2003, p.68). Nevertheless, participation in the global economy is viewed as essential to the goals of self-preservation and development (Anderson, 1995; Redpath and Nielson 1997; Thomas, 1994). 
Sutyrin and Vorobieva wrote,

\begin{abstract}
"Indigenous people of the Arctic, due to their traditional isolation and unique lifestyle, may be considered, among several social groups, most sensitive to globalised development ... The Arctic community and its advocates have the following options regarding the negative impact of globalisation on the Arctic: they may oppose it; bring an end to it; simply ignore it; or adapt and adjust to it." (Sutyrin and Vorobieva, 2005, p.756)
\end{abstract}

We can identify, then, several alternatives:

- Some people believe that there are benefits to assimilation into mainstream society in a global environment (Dana, 1993).

- An Indigenous society may wish to refrain from globalisation. This is the case of the U'wa in Colombia (Anderson et al., 2005).

- Some Indigenous societies wish to participate in the global economy, but "on their own terms" (Peredo et al., 2004, p.5), as is the case in the Mackenzie River Delta (Anderson et al., 2006).

\title{
3 Who are the Sámi people?
}

In former times, the Sámi people were commonly referred to as Lapps. Ruong (1937) provided a rich literature review of early studies about these people citing, among others, ethnographic studies of Sámi people in Sweden such as von Düben (1873) and later research conducted in Finland by Isac Fellman and Jacob Fellman.

Whitaker noted a definition: "a Lapp was defined as a person of Lappish origin whose father or mother, or one of their parents, was a full-time reindeer breeder" (Whitaker, 1955, p.25). Sámi people introduced reindeer herding to North USA and to Greenland.

Rather than define ethnicity based on occupation, more recent definitions are based on language. In Finland, the

\footnotetext{
"State Commission decided to include as Lapps (Same), those persons who spoke the Lapp language and who had at least one parent who spoke Lapp as a native language." (Ohlson, 1960, p.28)
}

Since 1996, Finland considers an individual to be Sámi if:

- the person considers himself/herself to be Sámi and has learned a Sámi language as mother-tongue

- the person considers himself/herself to be Sámi and a Sámi language was the first language of at least one parent or grandparent

- the parents or grandparents were recorded as a Lapp in 1932 or earlier.

Today, there are over 80,000 Sámi people, of whom slightly more than half reside in Norway (Sara, 2000). In Finland, Utsjoki is the only municipality in Finland where Sámi speakers are a majority of the population. Pelto and Müller-Wille noted that 
"The Utsjoki herders are descendants of Northern Reindeer (Mountain) Lapps, who were keepers of large herds in the 18th and 19th centuries when the Skolt Lapps were still making their living from fishing and reindeer hunting." (Pelto and Müller-Wille, 1972, 1973, p.120)

\section{Historical overview}

Müller-Wille wrote,

“originally, the various Sámi populations, living by hunting, fishing, gathering and herding in maritime and terrestrial ecosystems, obtained their food with high protein and fat contents from edible mammals ... such as wild reindeer, elk (moose), bear, beaver, fisher, squirrels and to a lesser degree, from hare, glutton (wolverine), lynx, marten (excluding clearly wolf and $\mathrm{dog}$ ) and marine animals such as seals, beluga whale, walrus." (Müller-Wille, 2001, p. 91)

In time, the reindeer achieved a prominent position with respect to food, as well as transport.

According to Vorren (1960) reindeer hunting was replaced during 16th century, by domestic reindeer management. The Sámi people thus evolved from being a food-extracting society to a food-producing society; they developed a subsistence economy, around the domestication of reindeer. Paine speculated,

"Lapp pastoralism was probably never on a large scale, and is most worthy of note for the husbandry of reindeer as well as sheep and cattle. The reindeer had been especially valued as decoy and transport animals; later, as wild reindeer hunting became less common, so the tame reindeer came to be valued for their milk products and as one source of meat supply." (Paine, 1958, p.171)

Clarke described the traditional way by which reindeer were slaughtered,

"attended with the least pain to the animal, and the greatest profit to its possessor. They thrust a sharp-pointed knife into the back part of the head, between the horns; so as to divide the spinal marrow from the brain. The beast instantly drops and expires without a groan or struggle, as if it fainted. The blood is not suffered to flow; but is collected afterwards into a pail from the stomach, yielding about two gallons: it is then used for food." (Clarke, 1824b, p.173)

It will be shown later, that European Union legislation now causes inefficiencies with regards to slaughtering, along with a move away from environmentally-friendly sustainability.

Elbo (1952) explained that reindeer and their herders traditionally migrated across national borders. Pelto and Müller-Wille $(1972,1973)$ discussed the case of the Utsjoki herders who travelled with their herds from Finland to Norway and back. Following their herds, these people were considered to be nomads. Ruong explained,

"By nomads one means pastoral peoples whose herds require large tracts of open country. From this it follows that the nomad must migrate and frequently change his place of abode. The frequency of migration and the degree of permanent settlement are convertible terms and thus different aspects of the same phenomenon, inasmuch as a low frequency of migration implies a high degree of permanent settlement and vice versa. One may thus speak now only of the frequency of migration and now only of the degree of permanent settlement." (Ruong, 1956, p.105) 
Whitaker $(1955$, p.35) noted that a Sámi by the name of N.M. Fjällström reported, "a family of three would require 20 reindeer for their own personal needs (i.e., food), apart from those sold to bring in income". Siuruainen and Aikio (1977) confirmed that a family would need to own between 250 and 300 registered reindeer to exist without other income.

Paine wrote, "Families fished for home consumption primarily but also for a commodity of barter" (Paine, 1958, p.171). Ruotsala (1999) noted that until the 1970s, reindeer herders supplemented their subsistence income with berry-picking, fishing and hunting and this provided for all one's needs. Siuruainen and Aikio (1977) explained that cloudberries (Rubus chamaemorus), were collected for barter, but the collection of berries on a commercial scale eventually became a widespread practice. Varieties include bilberries (Vaccinium myrtillus); bog whortleberries (Vaccinium uliginosum); cranberries (Vaccinium oxucoccos); crowberries (Empetrum nigrum) and red whortleberries (Vaccinium vitis-idaéa).

Müller-Wille and Pelto observed occupational clustering along ethnic lines,

"The Finns are mostly employed in administration, construction, and services whereas most of the Lapps still follow their traditional occupations - fishing, trapping, small farming, and reindeer herding." (Müller-Wille and Pelto, 1971, p.142)

Traditional occupations, however, could not support the rising population.

\section{Reindeer herding, globalisation and change}

Cultural values of a society determine the desirability of different forms of economic activity and the acquisition of knowledge. Entrepreneurship is then embedded in the cultural and social heritage of a society. Among the Sámi, reindeer herding has long been a desirable form of self-employment.

Reindeer herding in Finland represents a lifestyle and occupation for about 1,000 families who rely on approximately 200,000 reindeer (Hukkinen et al., 2003). While any citizen of the European Union who is permanently domiciled in a reindeer area of Finland may breed reindeer, Norway and Sweden reserve reindeer husbandry for Sámi people. In Finland, a local reindeer association managed by Sámi people is called paliskunta; this is essentially a system of cooperative or associational management, among self-employed reindeer owners.

Unlike entrepreneurs who compete against one another in other cultural contexts, the success of each Sámi reindeer herder has traditionally been dependent on the mutual cooperation of reindeer herders. The herding unit is known as a sii'dâ. As detailed by Whitaker, "The basis of the sii'dâ is a network of kinship ties" (Whitaker, 1955, p.57).

Müller-Wille and Pelto (1971) described the introduction of snowmobiles into reindeer herding in 1962, when the Sámi of Utsjoki were the first in Finland to use snowmobiles for herding. Pelto and Müller-Wille elaborated,

"the use of reindeer sleds for any sort of transportation was almost completely obsolete by 1967 and even economically marginal households throughout northern Lapland found means to purchase machines during the late 1960s." (Pelto and Müller-Wille, 1972, 1973, p.119) 
It may be argued that this led to the encouragement of over-consumption and over development at the cost of the environment.

Jääskö noted,

"Mechanisation and other general developments in the last decades have led to the situation where women's formerly unremunerated work has lost its importance ... The reindeerman no longer even needs a 'peski' (fur coat) or fur boots to keep him warm on the tundra. Thus, not only do machines directly assist in reindeer herding work, but even cloth weaving machines in India and sewing machines in Portugal reduce the need for work power ...." (Jääskö, 1999, p.37)

Bjørklund (2004, p.127) added, "a fast-growing supply of consumer goods only contributed to an expanding cash economy and its stresses".

Anderson summarised the change,

"where the herder's life once revolved entirely around the reindeer, which provided not only meat and milk but also materials for garments and tools, now the animals more and more are handled as a cash crop. Today the reindeer Lapp needs folding money to buy ever more abundant processed foods, ready-made clothing, automobiles, television sets and radios." (Anderson, 1977, p.371)

As was the case with other Indigenous people, activities "became dependent on goods produced outside their sphere of influence and introduced into their area of residence by external forces" (Müller-Wille, 1978, p.112). In the words of Riseth,

"The production system changed from subsistence pastoralism to a motorised and market-oriented industry, moving away from a near-complete dependence on animal and human muscle power to a degree of dependence on motorised vehicles." (Riseth, 2003, p.231)

\section{Methodology}

"Asking questions and getting answers is a much harder task than it may seem at first" (Fontana and Frey, 2003, p.61). A mail survey is of little use in the context of Sámi self-employment, which often takes place in the reindeer herding sector, where participant observation (e.g., unstructured interviewing and direct observation) is more appropriate, as discussed by Bruyn (1966), Jorgensen (1993) and Spradley (1997), among others.

Müller-Wille and Hukkinen (1999) and subsequently Hukkinen et al. (2006) outlined participatory research in the context of the Sámi people. Sámi culture is like a house and researchers must step into it, only after a door has been opened by a respected Sámi person. This makes the outsider become someone's väärti, as Sámi people call people from different cultures, who are allowed to participate in Sámi life. Being väärti enabled us to increase the reliability of our research. In exchange, väärti are expected to contribute to the Sámi community and not allowed to use gained knowledge against the benefit of Sámi society. This is consistent with Sámi epistemology, according to which an individual is a part of society and the individual's survival is dependent on the society, making loyalty essential. To contribute to the Sámi community meant participatory observation. As explained by Whitaker a "requirement of this method of research is that the field-worker shall not merely observe, but shall also participate" (Whitaker, 1955, p.11). Content validity was enhanced by means of triangulation 
(Patton, 1982, 1987, 1990) during participatory observation. Participatory observation also enhanced our awareness of the Sámi concept of knowledge. The concept of knowledge within Sámi culture is societal and it is formed by discussing. When speaking, Sámi often use the term 'we' rather than 'I'.

It is essential that the researcher be respectful, in order for research to be successful. Once accepted as a vä̈rti, the researcher should take care that the methods of gaining knowledge are in line with Sámi concept of knowledge. It is imperative not to hurry, in the quest to obtain information.

We benefited from snowball sampling (Goodman, 1961), of interviewees - a method that involves asking those already interviewed to identify who else they think should be invited to participate in the study. Interviewing stops only when the last respondent can only suggest individuals already named by others. This method proved successful in previous research dealing with the Sámi People (Müller-Wille and Hukkinen, 1999). Interviews in Finland were conducted in Finnish, by Merja Kilappa and by Liisa Remes of Jyväskylä. Those in Norway were conducted in Norwegian, by Elin M. Oftedal of the Bodø Graduate School of Business. Interviews in Sweden were conducted in English.

Barth (1969) suggested that the Sámi may be described as a population that defines itself across international boundaries by self-ascription. For the purpose of this study, Sámi identity was based on self-identification. On the subject of self-identification, Eythórsson noted

\begin{abstract}
"the relatively sudden 'disappearance' of the coastal Sámi from the census records ... when people who had classified themselves as Sámi in the pre-war census classified themselves as Norwegians in the first post-war census." (Eythórsson, 2003, p.151)
\end{abstract}

\title{
7 Findings
}

In contrast to Fraser (1937) who associated entrepreneurs with the management of a business unit, profit taking and business innovation, our self-employed respondents tended to express a love for the non-business side of reindeer herding, and there were several complaints that globalisation and the European Union are forcing them to look more at business management and profit. One interviewee expressed that when he was young his family seldom needed cash, because they did not need to buy much, other than matches. He continued to say that they valued non-monetary returns as opposed to financial profits. His wife interjected by saying that now they must pay for everything that comes from everywhere!

While Belshaw stated, "innovation is not a necessary criterion, but expansive management is" (Belshaw, 1955, p.147), and Dunkelberg and Cooper (1982) discussed growth-oriented entrepreneurs, growth in the number of reindeer owned is desirable for reindeer herders but restrained by external factors. Yet, none of our interviewees mentioned growth of their secondary enterprises. They express a preference for growth in their herds, but this does happen by increasing one's number of employees.

A herder in his late 40 s said that he had no employees and would never want any. When asked about ambitions, he replied that his goal was to make 'just enough' money to live. He and his son both mocked others who yearned for lots of money. Yet, they recognised that supplementary cash was required and since expansion was not an option, the father used reindeer antlers to make key-chains and bottle-openers to sell to Swedes. 
Cash was required to pay for a mobile telephone, a computer and access to the internet. The son exclaimed, "We do not want to be cut off from the world!"

Ulla Pirttijärvi-Länsman, a self-employed Sámi reindeer-owner ${ }^{4}$ whom we interviewed in Finland, is a famous singer who specialises in yoiking, the traditional music of reindeer herders. ${ }^{5}$ Globalisation is good for her, inasmuch as her recordings can be easily purchased around the world. Yet, she mentioned a particular love for her people and her country. In general, Sámi respondents focused discussions on the fact that they 'belonged' to their people, and that being an entrepreneur was a requirement in order to remain on their traditional homeland and to preserve their cultural heritage.

Many emphasised that Sámi entrepreneurship was traditionally centred on reindeer herding, but that globalisation 'pushed' Sámi individuals into formal entrepreneurship, in order to make a living without leaving their traditional lands. Herding is an important source of income for Sámi herders and this may account for about two thirds or more, of total income. In the words of one respondent in Norway, however, "it has become an expensive form of subsistence and we have to pay cash for the helicopter". A herder's income is usually complemented by his wife's salary, or by part-time agricultural or forestry work. For some, fishing provides food and extra income. In some cases, economic survival depends on a wife's salary.

Nils, a Sámi entrepreneur, born in Sweden, owns and operates a hotel in order to supplement his traditional form of income. He explained that globalisation 'pushed' him into the business, as traditional reindeer herding did not provide the cash ${ }^{6}$ necessary to maintain the standard of living that he chose for himself. With only 7 th grade education, he was not qualified to engage in professions requiring additional skills. Having worked abroad, he no longer wanted to live outside Fenno-Scandia. Thus, he became the owner and manager of a hotel, 'by necessity'. In his 50s, his five year plan was to sell the hotel, pay back his bank loan and become a full-time herder, supplementing his income with proceeds of the hotel sale. Never having more than two employees, he had no desire to expand his enterprise. With a reindeer herd that would give birth to 500 calves each year, he said that he could slaughter 300 reindeer annually, and live well, without the hotel. He then explained the identification system of reindeer, as illustrated in Figure 2.

Figure 2 Ownership of calves is identified by earmarks

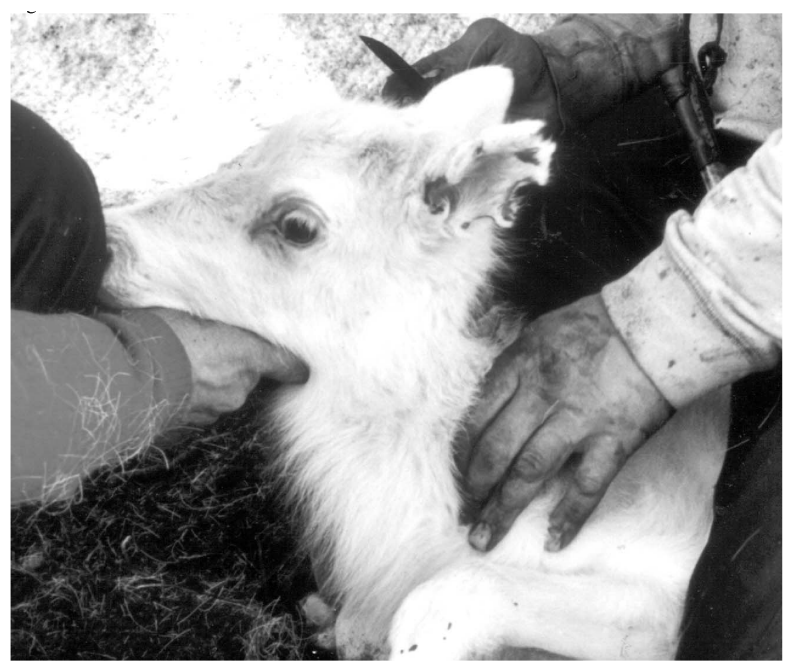


Many interviewees said that they were reindeer herders because that was their lifetime occupation and they never considered doing anything else. Much was said about the European Union regulation that impaired traditional self-employment and self-reliance. Commonly expressed sources of difficulties for Sámi herders included European Union legislation and the Western concept of competition. Sámi respondents in Finland indicated that they would like more contact with Sámi people in Norway and Russia, than with other Europeans in the Union. Sámi entrepreneurs in Norway complained that they suffer from the fact that Finland and Sweden are becoming increasingly integrated into the European Union.

A common concern amongst Sámi interviewees in Finland was that new regulation required reindeer to be trucked 'faraway to be killed'. One respondent explained,

\begin{abstract}
"The European Union assumes that we are slaughtering animals in temperatures that are similar to those in the Mediterranean countries, where there are many insects and germs that can attack meat. During our winter, it is so cold at this latitude that meat keeps fresher, but they want the animals to be killed 1,000 kilometres in the south."
\end{abstract}

A man recalled, "Until recently, we killed the animals here, painlessly and they did not suffer. The trucks frighten them". Another said, "When we slaughtered them here, we used all the parts and the blood was given to the earth. Now so much is wasted". Being more familiar with nature and their actual enterprises, than with accounting principles, Sámi entrepreneurs often complained about book-keeping requirements imposed by their respective nation-states.

Ani and Jarmo, a Sámi couple, aged in their 60 s, said that they had no formal education, but they had learned animal husbandry as children, during the 1940s. Like their parents, who served as mentors, they were subsistence reindeer herders. They always lived in Finland, but they recalled, with a smile, that they used to travel to Sweden for the purpose of purchasing matches, with which they would light fires. They lived in a tent until 1965, at which time they settled in a permanent house. They expressed their common wish to be traditional reindeer herders forever; they said that this made them feel like respected people. They repeatedly complained that the European Union impeded the survival of traditional methods. They said that although technology has facilitated transport, ${ }^{7}$ life was much better during the 1950s, than at any time after that. They resented the high cost of imported fuel. They also specified an aversion toward risk; they disliked the risk of being retired and they criticised the Government for its interventionist policies. They said that it was unfair of the state to force a herder to retire at any age; they perceived themselves as fit to work and earn an honest living and they did not want to be dependent on an old-age pension for survival. They also complained that new legislation allowed only one of their offspring to inherit the family herd. They explained that, in former times, nobody needed to borrow money. More recently, they learned to mistrust non-Sámi Finns, because some sales were never paid for.

A Sámi man, Pentti, said that he was 'pulled' to reindeer herding for the freedom and the lifestyle that it allowed. Having always lived in the Arctic, he had learned the required skills as a youngster and in turn shared his passion with his 12 year old son, Tuomas, who was determined to have the same profession. Although each owned his respective reindeer, the father and son worked as a team. 
Other Sámi people identified new opportunities, in the changing environment. Nils-Samuli, born into a Sámi family, became a full-time 'wilderness guide', in addition to maintaining his herd. While he aimed to earn sufficient money to live on, he spoke of the danger of bringing in more tourists than nature could handle.

Besides questions relating to self-employment and globalisation, interviewees were asked to share some general knowledge. One Sámi respondent said that his advice was to always cut wood far away from one's living quarters, in order to keep trees nearby, in case of a storm. An older Sámi woman said that she learned from her parents to fish far away, so that there would always be fish nearby, in case of emergency. Another respondent said that spiritual heritage is more important than monetary gains. A valuable lesson was that subsistence resource harvest has an intrinsic value not measured in currency.

\section{Toward the future}

For the Sámi people, reindeer husbandry was traditionally an ideal livelihood given the conditions of the far north. Globalisation introduced a new reality. Integration of reindeer pastoralism into the global economy has been putting pressure on herders to rationalise their self-employment into a meat-packing industry. Herders are complaining about the new regulations and lack of efficiency. Thus, where Indigenous traditions and forms of production meet the institutions of the global market economy, some confusion and conflicts arise. In this case, it is true that "social opposition is between production for subsistence and production for the market" (Ingold, 1980, p.3).

Reindeer herding is still regarded as being of high cultural importance, but it usually requires other income. Based on our interviews, we have identified some trends. Sámi entrepreneurs are pulled to reindeer herding because of social conditioning, but to reduce their risks and to increase incomes, they are pushed into secondary enterprises (often modern professions in the service sector) from which they sometimes withdraw. They usually do not act for their individualistic gain, but on the account of the extended family. The Sámi entrepreneur often seeks to create employment for his family, but does not seek extended growth for his secondary enterprise; yet, he is happy to participate in the global economy, while retaining his culture and without assimilating into mainstream society.

The Sámi are happy to modernise. In some instances, helicopters are used for herding, along with cell phones and GPS systems. There is even talk of using satellite data for herding in the future. Reindeer meat is exported and the Sámi participate in the expanding global economy with a degree of self-determination. Yet, there is considerable frustration at some of the downsides of globalisation, which many respondents perceive will force Sámi people to move away from environmentally-friendly sustainable capitalism. Globalisation reduces the need for local jobs and it may impoverish the culture, as traditions are forgotten.

In the competitive global environment, reindeer herding is not as profitable as other sectors. Furthermore, the state does not encourage young reindeer owners sufficiently, and some shift to other occupations, forcing them to migrate from their traditional homeland. 
We did not interview those who may have chosen to assimilate, as we did not interview in the southern capitals. It may be said, then, that our sample was somewhat self-selected, in that all our interviews were conducted in the North. Nevertheless, what we were told repeatedly was that friends and relatives who have moved south soon yearn to return to their roots. It is thus apparent that the modernisation and dependency perspectives are mismatched with Sámi objectives relating to their traditions, culture and values, and the role that these are to play in development.

\section{Acknowledgement}

The authors express thanks to the following for their kind assistance and comments on the earlier version of this paper that was presented at the Fifth International Congress of Arctic Social Sciences, sponsored by the International Arctic Social Sciences Association, at the University of Alaska: Pekka Aikio, President, Sámi Parliament, Finland; Ulla Aikio-Puoskari, Giellagas Institute, Oulu University, Oulu, Finland; Kathleen Osgood Dana, Sterling College, Craftsbury Common, Vermont, USA; Harald Gaski, Department of Sámi, University of Tromsø, Tromsø, Norway; Leo Granberg, Professor of Rural Studies, Department of Social Psychology, University of Helsinki, Helsinki, Finland; Per Klemetsen Haetta, Deputy Head, Centre for Sámi Studies, University of Tromsø, Tromsø, Norway; Hannu I. Heikkinen, Department of Art Studies and Anthropology, University of Oulu, Oulu, Finland; Elisabet Ljunggren, Nordlandsforskning, Bodø, Norway; Ludger Müller-Wille, Department of Geography, McGill University, Montreal, Quebec, Canada; Jukka Nyyssönen, University of Tromsø, Tromsø, Norway; Anders Oskal, Innovation Norway; Kaisa Raitio, Department of Social Policy, Joensuu University, Joensuu, Finland; Torkel Rasmussen, Sámi University College, Guovdageaidnu, Norway; Jan Åge Riseth, Norut Social Science Research \& Nordic Sámi Institute, Tromsø, Norway; Helena Ruotsala, Department of Ethnology, Åbo Akademi University, Finland; Lars Rønning, Bodø Graduate School of Business/Nordland Research Institute, Bodø, Norway; Andde (Anders) Sara, Sámi University College, Guovdageaidnu, Norway; Trond Thuen, Department of Social Anthropology, University of Tromsø, Tromsø, Norway; Birger Winsa, Department of Finnish, Stockholm University, Stockholm, Sweden; and Bjørn Willy Åmo, Bodø Graduate School of Business, Bodø, Norway. The University of Missouri, at Columbia, was helpful in providing access to rare documents, such as Ruong (1937). Merja Kilappa and Liisa Remes were instrumental in translating between Finnish and English. Elin M. Oftedal and Anders Oskal were instrumental in translating between Norwegian and English. Elen Solbritt Eira was instrumental in translating between Sámi and English.

\section{References}

Aikio, P. (1993) 'Cultural sovereignty of northern aboriginal nations: the predicament of the Sámi', in Dorais, L-J. and Müller-Wille, L. (Eds.): Social Sciences in the North: Keynotes Presented at the Eighth Inuit Studies Conference and First International Congress of Arctic Social Sciences, International Arctic Social Sciences Association, Ste-Foy, Quebec, pp.15-21.

Anderson, R.B. (1995) 'The business economy of the first nations in Saskatchewan: a contingency perspective', Canadian Journal of Native Studies, Vol. 2, pp.309-346. 
Anderson, R.B., Camp II, R., Dana, L.P., Honig, B., Nkongolo-Bakenda, J-M. and Peredo, A.M. (2005) 'Indigenous land rights in Canada: the foundation for development?', International Journal of Entrepreneurship and Small Business, Vol. 2, No. 2, pp.104-133.

Anderson, R.B., Dana, L.P. and Dana, T.E. (2006) 'Indigenous land rights, entrepreneurship, and economic development in Canada: 'opting-in' to the global economy', Journal of World Business, Vol. 41, pp.45-55.

Anderson, S. (1977) ‘Norway’s reindeer Lapps’, National Geographic, Vol. 152, No. 3, September, pp.364-379.

Barth, F. (Ed.) (1969) Ethnic Groups and Boundaries: The Organisation of Cultural Difference, Universitetsforlaget, Oslo.

Barth, F. (1973) 'A general perspective on nomad-sedentary relations in the Middle East', in Cynthia, N. (Ed.): The Desert and the Sown: Nomads in the Wider Society, University of California Institute of International Studies, Berkley, California, pp.11-21.

Beach, H. (1993) A Year in Lapland: Guest of the Reindeer Herders, Smithsonian Institution Press, Washington DC.

Belshaw, C.S. (1955) 'The cultural milieu of the entrepreneur: a critical essay', Explorations of Entrepreneurial History, Vol. 7, No. 3, pp.146-163.

Berger, P.L., Berger, B. and Kellner, H. (1973) The Homeless Mind: Modernisation and Consciousness, Random House, New York.

Bjørklund, I. (1985) Fjordfolket i Kvaenangen: Fra Samisk Samfunn til Norsk Utkant 1550-1880, Universitetsforlaget, Oslo.

Bjørklund, I. (2004) 'Saami pastoral society in Northern Norway: the national integration of an Indigenous management system', in Anderson, D.G. and Nuttall, M. (Eds.): Cultivating Arctic Landscapes: Knowing and Managing Animals in the Circumpolar North, Berghahn, New York and Oxford, pp.124-135.

Bruyn, S. (1966) The Human Perspective in Sociology: The Methodology of Participant Observation, Prentice-Hall, Englewood Cliffs, New Jersey.

Buckingham, S. and Dana, L.P. (2005) 'Focus on regulation theory', International Journal of Entrepreneurship and Small Business, Vol. 2, No. 2, pp.178-187.

Clarke, E.D. (1824a) Travels in Various Countries of Europe Asia and Africa: Scandinavia, T. Cadell, London, Vol. 9.

Clarke, E.D. (1824b) Travels in Various Countries of Europe Asia and Africa: Scandinavia, T. Cadell, London, Vol. 10.

Corbridge, S. (1990) 'Post-marxism and development studies: beyond the impasse', World Development, Vol. 18, No. 5, May, pp.623-639.

Daes, E-I. (2003) 'Globalisation, intellectual property and Indigenous peoples', in Jentoft, S., Minde, H. and Nilsen, R. (Eds.): Indigenous Peoples: Resource Management and Global Rights, Eburon Academic, Delft, The Netherlands, pp.67-73.

Dana, L.P. (1993) 'An inquiry into culture and entrepreneurship: case studies of business creation among immigrants in Montreal', Journal of Small Business and Entrepreneurship, Vol. 10, No. 4, July-September, pp.16-31.

Degen, A.A. (2007) 'Traditional livestock production among Bedouin in the Negev desert', in Dana, L.P. and Anderson, R.B. (Eds.): International Handbook of Research on Indigenous Entrepreneurship, Edward Elgar, Cheltenham, UK, pp.115-136.

Denzin, N.K. and Lincoln, Y.S. (2003) 'The discipline and practice of qualitative research', in Denzin, N.K. and Lincoln, Y.S. (Eds.): The Landscape of Qualitative Research: Theories and Issues, 2nd ed., Sage, Thousand Oaks, California, pp.1-45.

Dicken, P. (1992) 'International production in a volatile regulatory environment', Geoforum, Vol. 23, No. 3, pp.303-316. 
Dunkelberg, W.C. and Cooper, A.C. (1982) 'Entrepreneurial typologies: an empirical study', in Vesper, K.H. (Ed.): Frontiers of Entrepreneurial Research, Babson College, Wellesley, Massachusetts, pp.1-15.

Dunning, J.H. (2003) 'An overview', in Dunning, J.H. (Ed.): Making Globalisation Good: The Moral Challenges of Global Capitalism, Oxford University Press, Oxford, pp.11-40.

Elbo, J.G. (1952) 'Lapp reindeer movements across the frontiers of northern Scandinavia', The Polar Record, Vol. 6, pp.348-358.

Eythórsson, E. (2003) 'The coastal Sami: a 'pariah caste' of the norwegian fisheries? a reflection on ethnicity and power in Norwegian resource management', in Jentoft, S., Minde, H. and Nilsen, R. (Eds.): Indigenous Peoples: Resource Management and Global Rights, Eburon Academic, Delft, The Netherlands, pp.149-162.

Fontana, A. and Frey, J.H. (2003) 'The interview: from structured questions to negotiated text', in Denzin, N.K. and Lincoln, Y.S. (Eds.): Collecting and Interpreting Qualitative Materials, 2nd ed., Sage, Thousand Oaks, California, pp.61-106.

Fraser, L.M. (1937) Economic Thought and Language, Black.

Goodman, L.A. (1961) 'Snowball sampling', The Annals of Mathematical Statistics, Vol. 32, No. 1, pp.148-170.

Graburn, N.H.H. (1981) '1, 2, 3, 4 ... anthropology and the fourth world', Culture, Vol. 1, No. 1, pp.66-70.

Hukkinen, J., Müller-Wille, L., Aikio, P., Heikkinen, H., Jääskö, O., Lakkso, A., Magga, H., Nevalainen, S., Pokuri, O., Raitio, K. and West, N. (2006) 'Development of participatory institutions for reindeer management in Finland: a diagnosis of deliberation, knowledge integration and sustainability', Ecological Studies, Vol. 184, pp.47-71.

Hukkinen, J., Müller-Wille, L. and Heikkinen, H. (2003) Development of Participatory Institutions for Reindeer Management in Northern Finland: Preliminary Synthesis and Report, Helsinki University of Technology, Espoo, Finland.

Huntington, S.P. (1993) ‘The clash of civilisation', Foreign Affairs, Vol. 72, No. 3, pp.22-49.

Huntington, S.P. (1996) The Clash of Civilisation and the Remaking of World Order, Simon and Schuster, New York.

Ingold, T. (1980) Hunters, Pastoralists and Ranchers, Cambridge University Press, Cambridge.

Jääskö, O. (1999) 'Women's position in reindeer herding economy: an environmental factor', in Müller-Wille, L. (Ed.): Human Environmental Interactions: Issues and Concerns in Upper Lapland, Finland, Arctic Centre, University of Lapland, Rovaniemi, pp.35-40.

Jorgensen, D.L. (1993) Participant Observation: A Methodology for Human Studies, Applied Social Research Methods, Vol. 15, Sage, Thousand Oaks, California.

Levy, M.J. (1966) Modernisation and the Structure of Societies: A Setting for International Affairs, Princeton University Press, Princeton.

Manker, E. (1953) The Nomadism of the Swedish Mountain Lapps: The Siidas and Their Migratory Routes in 1945, Translated by Pehrson, R.N., Hugo Gebers Förlag, Stockholm.

Moore, W.E. (1963) Social Change, Prentice-Hall, Englewood Cliffs, New Jersey.

Moore, W.E. (1979) World Modernisation: The Limits of Convergence, Elsevier, New York.

Müller-Wille, L. (1978) 'Cost analysis of modern hunting among the Inuit of the Canadian central Arctic', Polar Geography, Vol. 2, No. 2, pp.104-114.

Müller-Wille, L. (2001) 'From reindeer stew to pizza: the displacement of local food resources in Sápmi, Northernmost Europe', Fennia, Vol. 179, No. 1, pp.89-96.

Müller-Wille, L. (2007) 'Peoples, livelihoods, and change in Europe's far and Atlantic North', in Dana, L.P. and Anderson, R.B. (Eds.): International Handbook of Research on Indigenous Entrepreneurship, Edward Elgar, Cheltenham, UK, pp.195-200.

Müller-Wille, L., Heinrich, D., Lehtola, V-P., Aikio, P., Konstantinov, Y. and Vladimorova, V. (2006) 'Dynamics in human-reindeer relations: reflections on prehistoric, historic and contemporary practices in Northernmost Europe', Ecological Studies, Vol. 184, pp.27-45. 
Müller-Wille, L. and Hukkinen, J. (1999) 'Human environmental interactions in upper Lapland, Finland: development of participatory research strategies', Acta Borealia, Vol. 2, pp.43-61.

Müller-Wille, L. and Pelto, P.J. (1971) 'Technological change and its impact in Arctic regions: Lapps introduce snowmobiles into reindeer herding', Polarforschung, Vol. 41, pp.142-148.

Ohlson, B. (1960) 'Settlement and economic life in Enotekiö - a parish in the extreme North of Finland', Fennia, Vol. 84, pp.21-46.

Olson, A.L. (1938) 'The farthest-north republic: Olympic games and Arctic flying bring sequestered Finland into new focus of world attention', National Geographic, Vol. 74, No. 4, October, pp.499-534.

Paine, R. (1958) 'Changes in the ecological and economic bases in a coast Lappish district', Southwestern Journal of Entrepreneurship, Vol. 14, pp.168-188.

Patton, M.Q. (1982) 'Qualitative methods and approaches: what are they?', in Kuhns, E. and Martorana, S.V. (Eds.): Qualitative Methods for Institutional Research, Jossey-Bass, San Francisco, pp.3-16.

Patton, M.Q. (1987) How to Use Qualitative Methods in Evaluation, Sage, Newbury Park, California.

Patton, M.Q. (1990) Qualitative Evaluation and Research Methods, Sage, Newbury Park, California.

Peck, J. and Tickell, A. (1992) 'Local modes of social regulation', Geoforum, Vol. 23, No. 3, pp.347-363.

Pelto, P.J. and Müller-Wille, L. (1972, 1973) 'Reindeer herding and snowmobiles: aspects of a technological revolution', Folk, Vols. 14-15, pp.119-144.

Peredo, A.M.P., Anderson, R.B., Galbraith, C., Honig, B. and Dana, L.P. (2004) 'Toward a theory of Indigenous entrepreneurship', International Journal of Entrepreneurship and Small Business, Vol. 1, Nos. 1-2, pp.1-20.

Redpath, L. and Nielson, M.O. (1997) 'A comparison of native culture, non-native culture and new management ideology', Canadian Journal of Administrative Sciences, Vol. 14, No. 3, pp.327-339.

Richardson, L. (1997) Fields of Play: Constructing an Academic Life, Rutgers University Press, New Brunswick, New Jersey.

Riseth, J.A. (2003) 'Sámi reindeer management in Norway: modernisation challenges and conflicting strategies. reflections upon the co-management alternative', in Jentoft, S., Minde, H. and Nilsen, R. (Eds.): Indigenous Peoples: Resource Management and Global Rights, Eburon Academic, Delft, The Netherlands, pp.229-247.

Rostow, W.W. (1953) The Process of Economic Growth, Oxford University Press, Oxford.

Rostow, W.W. (1957) 'The interrelation of theory and economic history', Journal of Economic History, Vol. 17, December, pp.509-523.

Rostow, W.W. (1960) The Stages of Economic Growth: A Non-Communist Manifesto, Cambridge University Press, London.

Ruong, I. (1937) Geographica: Fjällapparna I Jukkasjärvi Socken, Appelbergs Boktryckeriaktiebolag, Uppsala, Sweden.

Ruong, I. (1956) 'Types of settlement and types of husbandry among the Lapps in Northern Sweden', Studia Ethnographica Upsaliensia, Vol. 2, pp.105-132.

Ruotsala, H. (1999) 'The reindeer herder's environment', in Müller-Wille, L. (Ed.): Human Environmental Interactions: Issues and Concerns in Upper Lapland, Finland, Arctic Centre, University of Lapland, Rovaniemi, pp.41-47.

Sara, Á. (2000) Interreg Sápmi Subprogram: Interreg III A Nordkalotten, 2000-2006, Sámi Instituhtta, Kautokeino, Norway.

Scott, A.J. (1988) New Industrial Spaces: Flexible Production Organisation and Regional Development in North America and Western Europe, Pion, London. 
Siuruainen, E. and Aikio, P. (1977) The Lapps in Finland: The Population, Their Livelihood and their Culture, Society for the Promotion of Lapp Culture, Helsinki, Finland.

So, A.Y. (1990) Social Change and Development: Modernisation, Dependency, and World-System Theories, Sage, Newbury Park, California.

Spradley, J.P. (1997) Participant Observation, Holt Rinehart and Winston, New York.

Storper, M. and Walker, R. (1989) The Capitalist Imperative: Territory, Technology and Industrial Growth, Basil Blackwell, New York.

Sutyrin, S.F. and Vorobieva, I.V. (2005) 'Globalisation in the Arctic', in Nuttall, M. (Ed.): Encyclopedia of the Arctic, Routledge, New York, Vol. 2, pp.754-759.

Thomas, K.C. (1994) 'The emergence of aboriginal business in Canada', Canadian Business Review, Vol. 21, June, pp.12-17.

Turi, J.M. (2002) 'The world reindeer livelihood - current situation, threats and possibilities', in Kankaanpää, S., Müller-Wille, L., Susiluoto, P. and Sutinen, M-L. (Eds.): Northern Timberline Forests: Environmental and Socio-economic Issues and Concerns, The Finnish Forest Research Institute, Kolari, Finland, pp.70-75.

von Düben, G. (1873) Om Lappland och Lapparne, Företrädesvis de Svenske, Stockholm.

Vorren, Ø. (1960) 'Lapp settlement and population', in Vorren, Ø. (Ed.): Norway North of 65, Oslo University Press, Oslo, pp.122-133.

Whitaker, I. (1955) Social Relations in a Nomadic Lappish Community, Utgitt av Norsk Folkemuseum, Oslo.

Youatt, W. (1866) Sheep, Their Breeds, Management, and Diseases, Simpkin, Marshall and Co., London.

\section{Notes}

${ }^{1}$ During the 19th century, the term Scandinavia included Finland (Clarke, 1824a); today, the term refers to Denmark, Norway and Sweden. Our research was conducted in the homeland of the Sámi people, a territory that transcends Finland, as well as Norway and Sweden, but not Denmark. Hence, we use the term Fenno-Scandia, which corresponds to areas with Finnish and Scandinavian heritage and languages, on and around the Fenno-Scandian Precambrian shield (Müller-Wille, 2007).

${ }^{2}$ See also: Barth (1973), Degen (2007) and Manker (1953).

${ }^{3}$ See also: Buckingham and Dana (2005).

${ }^{4}$ Like many other owners, she has other people taking care of her reindeer.

${ }^{5}$ For a discussion of the music of shepherds in the UK, see Youatt (1866).

${ }^{6}$ This supports Beach's view, "Money economy is no longer simply an attractive alternative affording luxuries and new comforts, it is a vital need." (Beach, 1993, p.25)

${ }^{7}$ For a discussion of the snowmobile revolution, see Müller-Wille (1978). 